\title{
Distribution and Use of Brood-rearing and Moulting Sites of the Atlantic Population of Canada Geese (Branta canadensis) in Nunavik, Quebec
}

\author{
RICHARD C. COTTER \\ Canadian Wildlife Service, 801 — 1550 Avenue d'Estimauville, Québec, Quebec G1J 0C3 Canada; email: richard.cotter@ec \\ .gc.ca
}

Cotter, Richard C. 2015. Distribution and use of brood-rearing and moulting sites of the Atlantic population of Canada Geese (Branta canadensis) in Nunavik, Quebec. Canadian Field-Naturalist 129(3): 229-236.

The Atlantic population of Canada Geese (Branta canadensis) nests in the coastal lowlands of eastern Hudson Bay and southwestern Ungava Bay in Nunavik, Quebec. Although many aspects of the nesting ecology of this and other northern populations of Canada Geese have been studied and published, there is a paucity of information on the use of brood-rearing and moulting sites. Based on 18 years of band and recapture data from an ongoing banding program, this paper presents the distribution of brood-rearing and moulting sites and the use of these sites over time. Along Hudson Bay and Ungava Bay, the most important brood-rearing and moulting areas are the stretch of coastal lowlands between the Mariet River and Shallow Bay and between Rivière aux Feuilles and Virgin Lake, respectively. Of all adult geese captured during the banding program $(n=41924), 7.5 \%$ (standard error [SE] 0.13\%) were recaptures, that is, birds that had previously been caught and banded; annual recapture rates ranged from $5.1 \%$ to $11.4 \%$. The mean and median distances between the site of first recapture and the original site of capture were $4.3 \mathrm{~km}$ (SE $0.22 \mathrm{~km}$ ) and $1.5 \mathrm{~km}$, respectively. Juveniles moved, on average, $5.4 \mathrm{~km}$ farther than adults and males moved $1.4 \mathrm{~km}$ farther than females. Among geese banded as juveniles, males moved twice as far as females: $11.5 \mathrm{~km}$ versus $5.7 \mathrm{~km}$.

Key Words: Canada Goose; Branta canadensis; Atlantic population; brood-rearing; moulting areas; dispersal; Nunavik; Quebec; Hudson Bay; Ungava Bay

\section{Introduction}

The Canada Goose (Branta canadensis) is one of North America's most widely distributed waterfowl species, as it nests in a broad range of habitats, including urban areas, prairie parklands, boreal forests, and taiga and tundra regions. Although the life history of the Canada Goose has been well studied (see review by Mowbray et al. 2002), there have been few studies of tundra-nesting populations because of the relatively high associated costs. Notable exceptions are the studies of populations of $B$. canadensis interior nesting along western Hudson Bay, Ontario; on Akimiski Island in James Bay, Nunavut; and in Nunavik, Quebec (Bruggink et al. 1994; Leafloor et al. 2000; Gan 2012; Cotter et al. 2013, 2014).

Although it is known that groups of flightless moulting Canada Geese are found in the same areas each summer (e.g., Sterling and Dzubin 1967) and that geese can show high fidelity to nesting areas (Cooke et al. 1975; Lindberg et al. 1995), there are few published quantitative data on repeat use and faithfulness to broodrearing and moulting sites. Previous use and the familiarity of such sites can provide ecological advantages to birds, such as improved feeding efficiency and knowledge of predators, but faithfulness to areas with deteriorating habitat conditions may be maladaptive (Lindberg and Sedinger 1998). The Atlantic population of Canada Geese nests exclusively in Quebec (Cotter et al. 2013; Rodrigue 2013) and has been the subject of an ongoing program, in which moulting family groups have been banded annually since 1997 (Cotter 2015). Each year, $5-11 \%$ of all adult geese captured have been captured and banded in a previous year (hereafter called recaptures).

The objective of our study was to identify key broodrearing and moulting areas, as well as to quantify distances between locations of first capture (and banding) and recapture of geese to help assess the importance of moulting areas to the Atlantic population of Canada Geese. Such information can help wildlife agencies manage and monitor this population on the breeding grounds more cost effectively and provide baseline data on the use of these areas by Canada Geese for environmental impact studies.

\section{Study Area}

The coastal areas of eastern Hudson Bay and southwestern Ungava Bay support the highest densities of the breeding Atlantic population of Canada Geese (Malecki and Trost 1990; Harvey et al. 2014). Both areas are located in the Southern Arctic Ecozone and are characterized by lower relief, numerous potholes and ephemeral ponds, herb-lichen tundra, and a cold, dry climate (Malecki and Trost 1990; Wiken et al. 1996).

\section{Methods}

Each year during 1997-2014, from late July to midAugust, four- to five-person crews searched these coastal areas (lowlands) by helicopter (Bell 206 Long Ranger, Bell Helicopter Textron Inc., Fort Worth, Texas, USA; and Eurocopter AS-350 A-Star and EC130, Airbus Helicopters, Marignane, France) for brood flocks of 


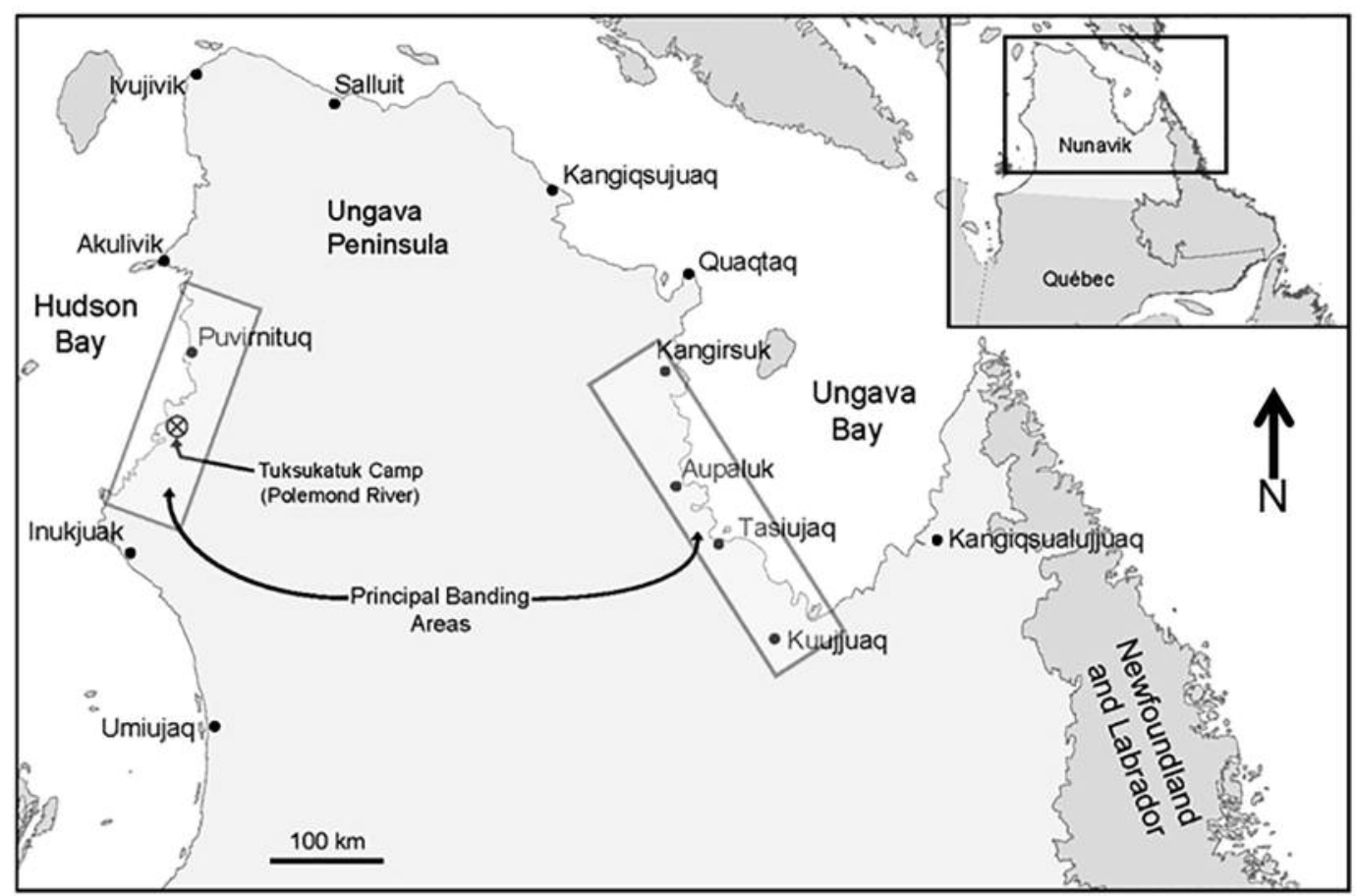

FIGURE 1. Map of the Ungava Peninsula, northern Quebec, showing the location of the Hudson Bay and Ungava Bay lowlands where banding of Atlantic population Canada Geese (Branta canadensis) was carried out from 1997 to 2014.

geese to capture and band (Figure 1). By the time of banding, adult geese had moulted their remiges and were flightless, and goslings were 4-6 weeks old.

Brood flocks ranging from 20 to 80 birds (both adults and goslings) were captured using a technique similar to Heyland (1970) and Leafloor and Rusch (1997). Each captured goose was fitted with a standard numbered United States Fish and Wildlife Service aluminium leg band, and the age (adult: after-hatch year [AHY]; juvenile: gosling) and sex (determined from cloacal examination) were recorded for all individuals. For adult females, the presence or absence of a brood patch was also recorded, with presence indicative of females that had laid eggs that year (Hanson 1959). Geographic coordinates (universal transverse mercator [UTM]) for each catch site were determined using a Garmin handheld Global Positioning System unit (models 48 and 76, Garmin, Olathe, Kansas, USA).

Along Hudson Bay, the base of operations was Tuksukatuk Camp, located on the Polemond River, although fuel and supplies were purchased at Puvirnituq, $60 \mathrm{~km}$ to the north (Figure 1). Two helicopters and crews operated simultaneously, except in 1997 and 2012-2014 when only one helicopter and crew banded. Each year, each crew banded for an average of nine days and flew 25 hours. All catch sites were located between the coast and approximately $50 \mathrm{~km}$ inland and between the Inuit communities of Inukjuak and Akulivik (Figure 1), but most sites were between the
Mariet $\left(59^{\circ} 9^{\prime} \mathrm{N}\right)$ and Sorehead $\left(60^{\circ} 31^{\prime} \mathrm{N}\right)$ rivers (Figure 2).

Banding effort over the various areas of the lowlands for moulting family groups was fairly consistent among years, with the following two exceptions. First, between 1997 and 2003, in a $32.8 \mathrm{~km}^{2}$ area along the Polemond River, an intensive nesting ecology study of Atlantic population Canada Geese was carried out (described in Cotter et al. 2013). Part of this study included webtagging goslings at hatching and recapturing them during the banding operations to calculate gosling survival rate. Consequently, in these years, extra time and effort was expended by the banding crew in this area to catch as many family groups (and web-tagged goslings) as possible. Second, the area between Puvirnituq and the Sorehead River was not searched systematically but, instead, the crew flew in a fairly straight line between those locations, because of range and fuel concerns, although at a sufficiently low altitude and speed to detect family groups.

Along Ungava Bay, a single crew was based at either Kuujjuaq (1997-2011) or Aupaluk (2012-2014); each year, this crew banded on average for nine days and flew 33 hours. All catch sites were located between Kangiqsualujjuaq (on the George River) $\left(58^{\circ} 42^{\prime} \mathrm{N}\right.$, $\left.65^{\circ} 57^{\prime} \mathrm{W}\right)$ and the Virgin Lake area $\left(60^{\circ} 8^{\prime} \mathrm{N}\right)$, approximately $15 \mathrm{~km}$ northeast of Kangirsuk (Figure 1). The main banding area (representing $>95 \%$ of all catches), however, extended from Qikirtajuaq Island (also known as Big Island), located at the mouth of Rivière à la 


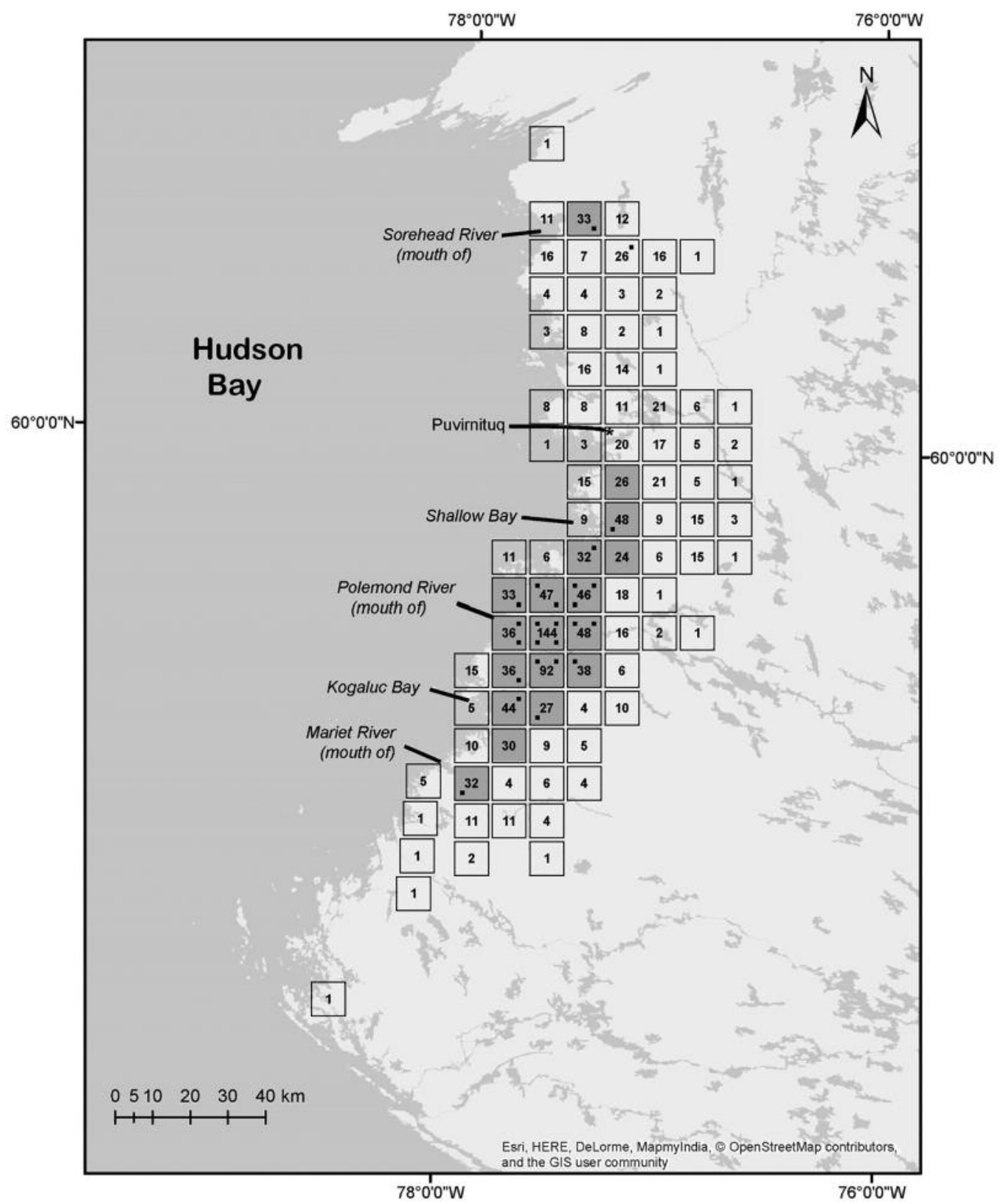

Figure 2. Map of Hudson Bay, northern Quebec, with distribution of $10 \mathrm{~km} \times 10 \mathrm{~km}$ squares where Atlantic population Canada Geese (Branta canadensis) were captured and banded from 1997 to 2014. The number inside each square is the total number of catches made over the 18-year period. Squares in which geese were captured in 12 or more years are shaded grey. Quadrants $\left(25 \mathrm{~km}^{2}\right)$, within a square, in which geese were captured in nine or more years are indicated as small black square symbols.

Baleine, to the Virgin Lake area (Figure 3). In the 1990s, Qikirtajuaq Island was a major nesting and banding area, but, in the early 2000s, American Black Bears (Ursus americanus) began preying heavily on goose nests, with the consequence that, by 2005 , few geese were nesting on the island (Cotter et al. 2014). To compensate for the loss of this important nesting, and hence banding, site, crews increased their banding effort north of the Rivière aux Feuilles and ceased operations east of Rivière à la Baleine entirely, as it became inefficient to use helicopter time to work in this area which had lower brood flock densities. 


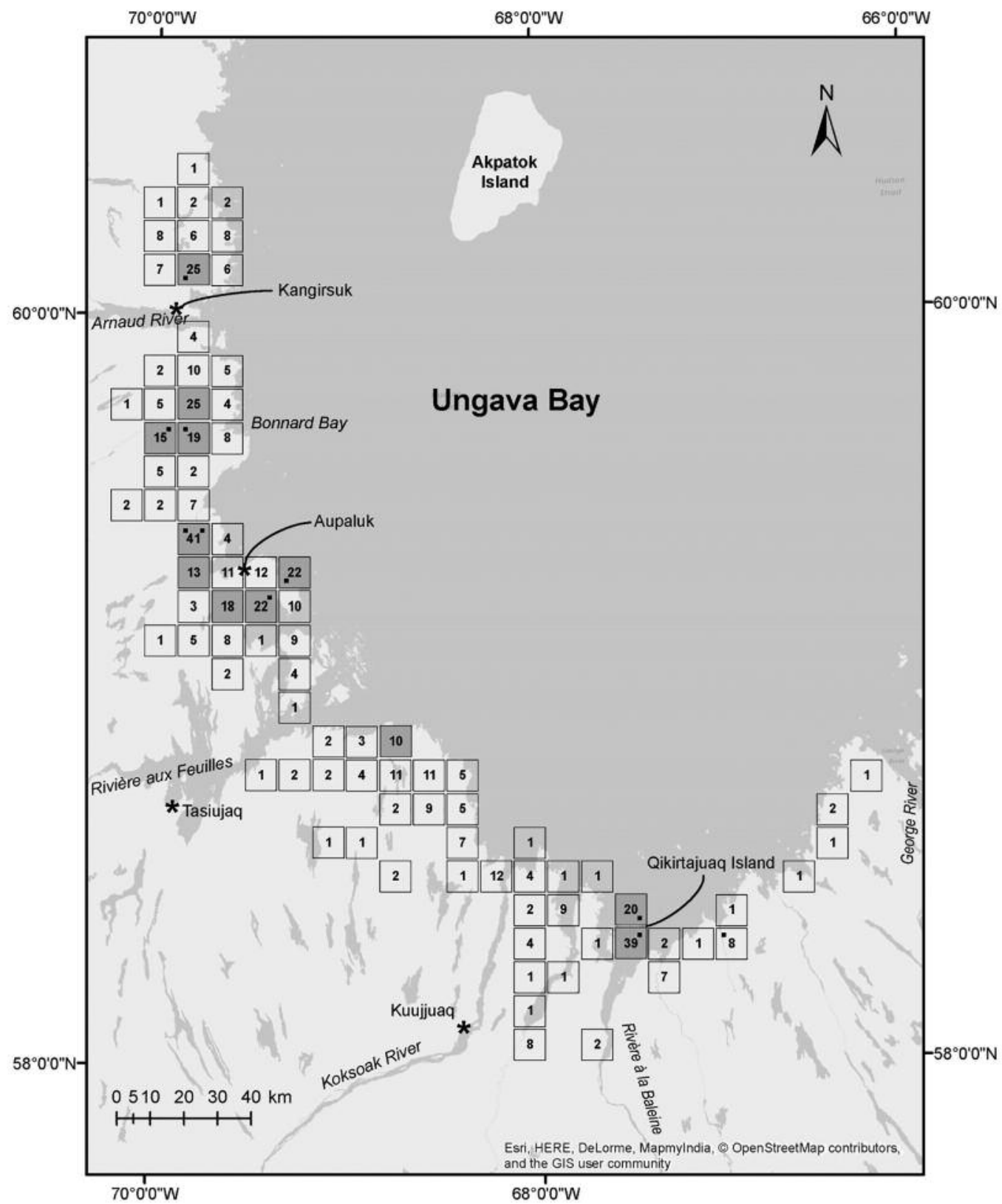

Figure 3. Map of Ungava Bay, northern Quebec, with distribution of $10 \mathrm{~km} \times 10 \mathrm{~km}$ squares where Atlantic population Canada Geese (Branta canadensis) were captured and banded from 1997 to 2014 . The number inside each square is the total number of catches made over the 18-year period. Squares in which geese were captured in nine or more years are shaded grey. Quadrants $\left(25 \mathrm{~km}^{2}\right)$, within a square, in which geese were captured in seven or more years are indicated as small black square symbols.

To analyze the distribution of moulting and catch sites, for each year, I calculated the number of catches per $100 \mathrm{~km}^{2}$ (i.e., $10 \mathrm{~km} \times 10 \mathrm{~km}$ squares using a UTM grid system, the same system and square nomenclature used by Gauthier and Aubry (1996: 71) in the Quebec breeding bird atlas; a grid of survey squares in a
Google Earth file is available online at the web site of the second Quebec atlas (http://www.atlas-oiseaux .qc.ca/googleearth_en.jsp). These squares were plotted on a topographic base map using ArcGIS 10.1 (ESRI, Redlands, California, USA) with the total (all years combined) number of catches per square. 
To examine distribution and use at a larger scale, I divided each square into four $25-\mathrm{km}^{2}(5 \mathrm{~km} \times 5 \mathrm{~km})$ quadrants: southwest (sw), northwest (nw), northeast (ne), and southeast (se). For each square and its four quadrants, I calculated the number of years catches were made. As a measure of regular (i.e., consistent) use across years for Hudson Bay, I set a criterion of 12 years (representing two-thirds of the 18-year banding period) and 9 years (one-half of banding period) for squares and quadrants, respectively, while for Ungava Bay, I set the criterion at 9 years and 7 years for squares and quadrants, respectively.

The mean distance $(\mathrm{km} \pm$ standard error [SE]) between capture locations was calculated for all recaptures combined, as well as for subgroups (example, Hudson Bay versus Ungava Bay), using the statistical software SAS (PROC MEANS, SAS Institute, Cary, North Carolina, USA). That is, for an individual recaptured goose, I calculated the distance between the site where it was recaptured and the site where it was originally captured and banded. A number of birds were recaptured in multiple years and, therefore, to control for non-independence, I used only the first recapture of each bird. For Hudson Bay and Ungava Bay, I tested for effects of sex, age at banding, and interval (number of years between initial capture and the recapture), and included year as a random variable, in a generalized linear mixed model (PROC GLM). The significance level was set at a $<0.05$ for all tests.

\section{Results}

Distribution of brood-rearing and moulting sites

Between 1997 and 2014, 96816 Canada Geese were captured and banded in 1917 catches. These catch sites were distributed over 175 100-km² squares along Hudson Bay $(n=88$; Figure 2$)$ and Ungava Bay $(n=$ 87; Figure 3). Among all squares along Hudson Bay and Ungava Bay, 18 and 12 squares were used "regularly," respectively. For the two regions, the total number of catches (years combined) in these squares ranged from 24 to 144 and 10 to 41 , respectively.

For Hudson Bay, however, the largest number of catches made in a single square would be 48 if the two squares (with 144 and 92 catches) encompassing the nesting study area (see Methods) were excluded. For Hudson Bay, all but one of the regularly used squares are located in a stretch of lowlands extending from the Mariet River in the south to just north of Shallow Bay. The exception is a square situated on the Sorehead River at the northern limit of the banding area (Figure 2). Sixty-one percent of all catches (816 of 1338) and $60 \%$ of total geese banded (34 419 of 56891 ) along Hudson Bay were from these 18 squares, and, in all but one of these squares, the total number of geese captured and banded over the 18 years was $>1000$. Fifteen of the squares had $\geq 1$ quadrant $\left(25 \mathrm{~km}^{2}\right)$ with catches in nine or more years (i.e., a regularly used quadrant) (Figure 2). The mean catch size along Hudson Bay was
42.5 geese (adults and goslings) (SE $0.68, n=1338$ catches); there was no difference in mean catch size between "regularly-used" and "non-regularly used" squares $(F=0.39, \mathrm{df}=1, P=0.53)$.

Along Ungava Bay, $46 \%$ of all catches (269 of 579) and $50 \%$ of total geese banded (20 153 of 39925 ) were from the 12 regularly used squares. The number of geese captured and banded over the 18 years was $>$ 1000 in 10 of these squares. Geographically, 9 of these 12 squares are located north of Rivière aux Feuilles and are concentrated in three areas: Aupaluk, Lefroy River (which empties into Bonnard Bay), and Virgin Lake. The regularly used squares south of Rivière aux Feuilles are located at Ragged Point and Qikirtajuaq Island (encompassing two squares) (Figure 3). Eight of the 12 squares had $\geq 1$ quadrants $\left(25 \mathrm{~km}^{2}\right)$ with catches in seven or more years (Figure 3).

Both Ungava Bay and Hudson Bay had one regularly used quadrant within a non-regularly used square. On Qikirtajuaq Island, from 1997 to 1999 over 1000 geese were banded annually, but this declined to an average of less than 300 geese per year between 2000 and 2005, due primarily to nest predation by black bears. Since 2005 , only two catches (each $<100$ geese) have been made there, one each in 2008 and 2009.

The mean catch size along Ungava Bay was 69.0 geese (adults and goslings) (SE 1.42, $n=579$ catches); the mean catch size in regularly used squares $(74.9 \pm$ $2.12, n=269)$ was significantly larger than that in nonregularly used squares $(63.8 \pm 1.88, n=310)(F=15.61$, $\mathrm{df}=1, P<0.01)$.

\section{Dispersal distances and site faithfulness}

From 1997 to 2013, 92698 Canada Geese were captured and banded in Nunavik, of which 2828 (3.1\%) different individuals were recaptured between 1998 and 2014. Whereas the majority were recaptured only once (91\%, 2580 of 2828 geese), many were recaptured in more than one year: 202 geese in two years, 41 in three years, 4 in four years, and 1 in five years, resulting in a total of 3128 recaptures over the 17-year period. Among recaptures, the median interval between initial capture and first recapture was three years (range: $1-16$ years). Of all recaptures, $28 \%$ (792 of 2828) were originally banded as goslings. Included in these recapture totals, but excluded in subsequent analyses, are two birds, both males and both originally captured as juveniles along Hudson Bay but recaptured as adults along Ungava Bay (individual distances of $415 \mathrm{~km}$ and $438 \mathrm{~km}$ ). These were the only geese to have switched regions. Also excluded were recaptures of Canada Geese $(n=209)$ that were not originally banded in Nunavik as part of this current program. I obtained from the Bird Banding Office (Canadian Wildlife Service) original banding data for all Canada Goose recaptures from 2005 to 2014, and $98.6 \%$ (1456 of 1477 geese) were originally banded in Nunavik (including four Canada Geese banded in Nunavik before 1997 as part of an earlier 
banding program) and $1.4 \%$ from states or provinces in the Atlantic and Mississippi flyways.

For all birds and years combined, the mean and median distances between the first recapture site and original (banding) capture site were $4.3 \mathrm{~km}$ and $1.5 \mathrm{~km}$, respectively (Table 1 ). Birds from Hudson Bay and Ungava Bay dispersed an average of $4.6 \mathrm{~km}$ and $3.8 \mathrm{~km}$, respectively. Juveniles moved on average $5.4 \mathrm{~km}$ farther than adults, whereas males moved $1.4 \mathrm{~km}$ farther than females. The sex difference among juveniles was even greater, with males dispersing on average twice as far as females, $11.5 \mathrm{~km}$ versus $5.7 \mathrm{~km}$ (Table 1). For both Hudson Bay and Ungava Bay, the sex difference was not significant (Hudson Bay: $F=2.51$, df $=1, P$ $=0.11$; Ungava Bay: $F=3.38$, df $=1, P=0.07)$, but age at initial capture, the interval (number of years) between initial capture and first recapture, and year were all highly significant $(P<0.01)$. For Hudson Bay, all interactions among the four variables were significant $(P<0.05)$, whereas for Ungava Bay only the yearinterval interaction was significant $(P<0.01)$.

Ninety-three percent (2630 of 2826) of all recaptures were within $10 \mathrm{~km}$ of their original banding location. Furthermore, nearly two-thirds (62\%, 1754 of 2826) were within $2 \mathrm{~km}$ and one-third (33\%, 943 of 2826) were within $1 \mathrm{~km}$ of their original banding location. The percentage of birds recaptured within $10 \mathrm{~km}$ of their original capture site was very similar between regions (Hudson Bay 92\% versus Ungava Bay 94\%) and sex (male $90 \%$ versus female $96 \%$ ), but less similar between the two age groups (adult $97 \%$ versus juvenile 83\%) (Figure 4). Among juveniles only, this percentage was lower for males (72\%) than females (91\%) (Figure 4).

TABLE 1. Descriptive statistics for the distances $(\mathrm{km})$ between original capture site and first recapture site in a subsequent year for all Canada Geese (Branta canadensis) combined (All), Hudson Bay, Ungava Bay, females (F), males (M), adults (A), juveniles (J), and juvenile females (JF) and juvenile males (JM), in Nunavik, northern Quebec, 1998-2014.

\begin{tabular}{lcccccccrr}
\hline \hline Subgroup & $n$ & Median & Mean & SE & CV & Min. & Max. & P10* & P90* \\
\hline All & 2826 & 1.476 & 4.269 & 0.220 & 0.273 & 0.017 & 187.775 & 0.437 & 6.437 \\
Hudson & 1577 & 1.487 & 4.607 & 0.303 & 0.261 & 0.039 & 130.431 & 0.423 & 7.197 \\
Ungava & 1249 & 1.467 & 3.842 & 0.317 & 0.291 & 0.017 & 187.775 & 0.450 & 5.963 \\
F & 1528 & 1.399 & 3.631 & 0.284 & 0.306 & 0.017 & 187.775 & 0.415 & 5.289 \\
M & 1298 & 1.635 & 5.021 & 0.341 & 0.244 & 0.020 & 178.736 & 0.468 & 9.926 \\
A & 2036 & 1.296 & 2.753 & 0.191 & 0.313 & 0.020 & 187.775 & 0.384 & 4.219 \\
J & 790 & 2.563 & 8.177 & 0.590 & 0.203 & 0.017 & 130.431 & 0.583 & 20.236 \\
JF & 454 & 1.885 & 5.738 & 0.688 & 0.256 & 0.017 & 130.431 & 0.474 & 9.131 \\
JM & 336 & 4.258 & 11.472 & 1.002 & 0.160 & 0.041 & 111.460 & 0.864 & 34.798 \\
\hline \hline
\end{tabular}

Note: $\mathrm{SE}=$ standard error, $\mathrm{CV}=$ coefficient of variation.

$* 10$ th and 90 th percentiles (i.e., $80 \%$ of $n$ falls within this range).
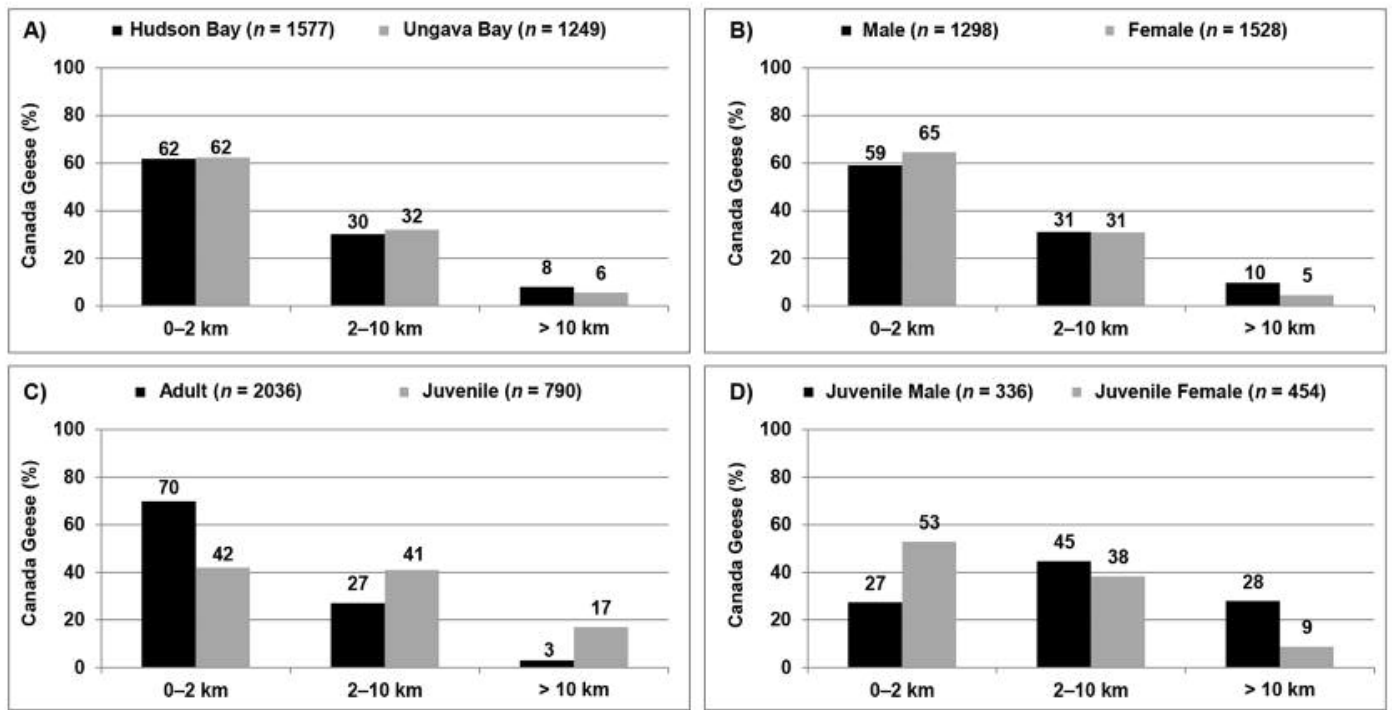

FIGURE 4. Percentage of Canada Geese (Branta canadensis) recaptured 0-2 km, 2-10 km, and $>10 \mathrm{~km}$ from original capture (banding) site, for four subgroups: A. Hudson Bay and Ungava Bay, B. Male and female birds, C. Birds first captured as adults versus juveniles, and D. Males and females first captured as juveniles. Sample size of each group is in parentheses. 


\section{Discussion}

For Canada Geese nesting along eastern Hudson Bay, Nunavik, there are two important brood-rearing and moulting areas: a $90-\mathrm{km}$ stretch of coastal lowlands extending north from the Mariet River to Shallow Bay (about $20 \mathrm{~km}$ southwest of Puvirnituq) and along the Sorehead River (about $60 \mathrm{~km}$ north of Puvirnituq), with both areas extending inland from the coast approximately $30 \mathrm{~km}$. Along Hudson Bay, over half of all catches and birds banded were from the 17 squares used "regularly" located in the Mariet River-Shallow Bay area. Along Ungava Bay, since the mid-2000s, three areas have been used consistently for brood-rearing and moulting (i.e., encompassing regularly used squares) and all are located north of the Rivière aux Feuilles: Aupaluk (20-km radius around the community), Lefroy River, which empties into Bonnard Bay, and Virgin Lake. A fourth area is Qikirtajuaq Island, a large island located south of Rivière aux Feuilles. This island was a major nesting and banding site in the 1990s, but in the early 2000 s nest predation by black bears increased dramatically and, as a consequence, the number of geese rearing broods and moulting there declined dramatically. As fewer and fewer geese were nesting and moulting south of Rivière aux Feuilles, banding effort in subsequent years was shifted to north of the river the percentage of all catches from south of the river declined from $60 \%$ for $1997-2005$ to $10 \%$ for 2006-2014. Because of this shift in banding effort from one area to another, for Ungava Bay a lower criterion for "regular" use for the $100-\mathrm{km}^{2}$ squares was used.

Pooling years and regions (Hudson Bay and Ungava Bay), $93 \%$ of recaptured geese moved $\leq 10 \mathrm{~km}$ from the site they were captured in an earlier year while $86 \%$ moved $\leq 5 \mathrm{~km}$. This latter percentage is very similar to that for Brant (Branta bernicla) on Banks Island where Cotter and Hines (2006) reported $88 \%$ of recaptures occurred within $5 \mathrm{~km}$ of their previous site of capture. Because goslings are unable to fly until mid-August, broods cannot move long distances between nesting and brood-rearing areas. In their study of Atlantic population geese nesting in the vicinity of Tuksukatuk Camp on the Polemond River, Cotter et al. (2013) reported that goslings (web-tagged at time of hatching) traveled an average of $7.2 \mathrm{~km}$ (median $=4.0 \mathrm{~km}$ ) from their nest to the site where they were captured at 4-6 weeks of age during the banding program. As geese show high fidelity to nesting areas (Cooke et al. 1975; Lindberg et al. 1995), this explains the commitment of Atlantic population Canada Geese to their broodrearing-moulting locations. For both Hudson Bay and Ungava Bay, there was no significant difference in distances moved by male and female geese, although there was an age effect with juveniles dispersing farther than adults. Compared with female Canada Geese in this study, female Snow Geese (Chen caerulescens) nesting on Bylot Island (Nunavut) moved longer distances; Mainguy et al. (2006) reported an overall average of
$25.6 \mathrm{~km}$ for Snow Geese but a considerable range $(2.6-52.5 \mathrm{~km})$ depending on the area selected by females to rear their brood.

In 2008, a management plan was produced for the Atlantic population of Canada Geese (Atlantic Flyway Council 2008). One of its objectives pertains to habitat management with a strategy to "monitor habitat conditions, potential development projects, and other threats to ensure protection of critical nesting and broodrearing habitats." As a step toward this objective, this paper provides quantitative data on the distribution of brood-rearing-moulting sites as well as faithfulness to these sites.

\section{Acknowledgements}

Financial support for the banding program was provided by the Canadian Wildlife Service, the United States Fish and Wildlife Service, and the Atlantic Flyway Council. A large number of people with these three organizations, as well as Makivik Corporation (Nunavik Research Centre), participated in the banding program and their help is greatly appreciated. I thank the following people, who for several years gave up their time in August for banding: Ed Robinson, Francis St-Pierre, Guillaume Tremblay, Jack Hughes, Joël Poirier, Josée Lefebvre, Kevin Jacobs, Peter May, Sandy Suppa, Pierre Brousseau, Jim Bennett, Jean Rodrigue, Sébastien Paradis, Shirley Orichefsky, and Ted Nichols. Sincere thanks to Ted Nichols for also reviewing this manuscript. I thank the Canadian Coast Guard, Ontario Ministry of Natural Resources and Forestry, and Nunavik Rotors, in particular the helicopter pilots, for their friendship and professionalism in flying as well as for their assistance on the ground with banding operations. The support given to this project by the Nunavik Hunting, Fishing, and Trapping Association is greatly appreciated, as is as the considerable help given each year with logistics by Aliva Tulugak in Puvirnituq.

\section{Literature Cited}

Atlantic Flyway Council. 2008. A management plan for the Atlantic population of Canada Geese. Atlantic Flyway Council Migratory Game Bird Technical Section, Laurel, Maryland, USA.

Bruggink, J. G., T. C. Tacha, J. C. Davies, and K. F. Abraham. 1994. Nesting and brood-rearing ecology of Mississippi Valley population Canada Geese. Wildlife monograph 126. Wildlife Society, Bethesda, Maryland, USA.

Cooke, F. C., C. D. MacInnes, and J. P. Prevett. 1975. Gene flow between breeding populations of Lesser Snow Geese. Auk 92: 493-510.

Cotter, R. C. 2015. Breeding ground banding of Atlantic Population Canada Geese in northern Québec - 2014. Canadian Wildlife Service, Quebec Region, Québec, Quebec, Canada. http://www.dnr.state.md.us/wildlife/Hunt_Trap/pdfs/2014 APCanadaGoose_BG-Banding.pdf

Cotter, R. C., and J. E. Hines. 2006. Distribution and abundance of breeding and moulting Brant on Banks Island, Northwest Territories. Pages 18-26 in Surveys of geese and swans in the Inuvialuit settlement region, western 
Canadian Arctic, 1989-2001. Occasional paper 112. Edited by J. E. Hines and M. O. Wiebe Robertson. Canadian Wildlife Service, Environment Canada, Ottawa, Canada.

Cotter, R. C., R. J. Hughes, P. May, P. Novalinga, J. Johannes, L. J. Hindman, and P. I. Padding. 2013. Breeding biology of Atlantic Population Canada Geese in Nunavik, Northern Quebec. Arctic 66: 301-311.

Cotter, R. C., R. J. Hughes, P. May, S. Suppa, P. Novalinga, J. Johannes, L. J. Hindman, and P. I. Padding. 2014. Atlantic Population Canada Goose Nesting Study and Monitoring Program in Nunavik, Quebec, 1996-2011. Technical Report 524. Canadian Wildlife Service, Environment Canada, Quebec Region, Québec, Quebec, Canada.

Gan, S. K. 2012. Factors influencing nesting success of subarctic breeding Canada Geese. M.Sc. thesis, Trent University, Peterborough, Ontario, Canada.

Gauthier, J., and Y. Aubry. 1996. The Breeding Birds of Quebec: Atlas of the Breeding Birds of Southern Quebec. Association québécoise des groupes d'ornithologues, Province of Quebec Society for the Protection of Birds, Canadian Wildlife Service, Environment Canada, Quebec Region, Montréal, Quebec, Canada.

Hanson, H. C. 1959. The incubation patch of wild geese: its recognition and significance. Arctic 12: 139-150.

Harvey, W. F., J. Rodrigue, and S. D. Earsom. 2014. A breeding pair survey of Canada Geese in northern Québec - 2014. Maryland Department of Natural Resources, Annapolis, Maryland, USA, and Canadian Wildlife Service, Quebec Region, Québec, Quebec, Canada. http://dnr.state .md.us/wildlife/Hunt_Trap/pdfs/2014_AP_Survey.pdf

Heyland, J. D. 1970. Aircraft-supported Canada Goose banding operations in arctic Quebec. Transactions of the Northeast Section of the Wildlife Society 27: 187-198.

Leafloor, J. O., and D. H. Rusch. 1997. Clinal size variation in Canada Geese affects morphometric discrimination techniques. Journal of Wildlife Management 61: 183-190.

Leafloor, J. O., M. R. J. Hill, D. H. Rusch, K. F. Abraham, and R. K. Ross. 2000. Nesting ecology and gosling survival of Canada Geese on Akimiski Island, Nunavut, Canada. Pages 109-116 in Towards conservation of the diver- sity of Canada Geese (Branta canadensis). Occasional paper 103. Edited by K. M. Dickson. Canadian Wildlife Service, Environment Canada, Ottawa, Ontario, Canada.

Lindberg, M. S., and J. S. Sedinger. 1998. Ecological significance of brood-site fidelity in black brant: spatial, annual, and age-related variation. Auk 115: 436-446.

Lindberg, M. S., J. S. Sedinger, and E. A. Rexstad. 1995. Estimating nest site fidelity of adult female black brant with multi-state modeling and geographic information systems. Journal of Applied Statistics 22: 725-735.

Malecki, R. A., and R. E. Trost. 1990. A breeding ground survey of Atlantic Flyway Canada Geese, Branta canadensis, in northern Quebec. Canadian Field-Naturalist 104: 575578.

Mainguy, J., G. Gauthier, J. F. Giroux, and J. Bêty. 2006. Gosling growth and survival in relation to brood movements in Greater Snow Geese (Chen caerulescens atlantica). Auk 123: 1077-1089.

Mowbray, T. B., C. R. Ely, J. S. Sedinger, and R. E. Trost. 2002. Canada Goose (Branta canadensis). In The Birds of North America: No. 682. Edited by A. Poole and F. Gill. Birds of North America, Inc., Philadelphia, Pennsylvania, USA.

Rodrigue, J. 2013. Canada Goose. Pages 44-54 in Status of Quebec Waterfowl Populations, 2009. Technical report 525. Edited by C. Lepage and D. Bordage. Canadian Wildlife Service, Environment Canada, Quebec Region, Québec, Quebec, Canada.

Sterling, T., and A. Dzubin. 1967. Canada Goose molt migrations to the Northwest Territories. Transactions of the North American Wildlife and Natural Resources Conference 32: 355-373.

Wiken, E., D. Gauthier, I. Marshall, K. Lawton, and H. Hirvonen. 1996. A perspective on Canada's ecosystems: an overview of the terrestrial and marine ecozones. Occasional paper 14. Canadian Council on Ecological Areas, Ottawa, Ontario, Canada.

Received 19 November 2014

Accepted 23 April 2015 